\title{
EARNINGS QUALITY: PRAKTIK DAN TELAAH KASUS GARUDA INDONESIA
}

\author{
Rachma Bhakti Utami ${ }^{1}$, Dinar Ary Kartikasari ${ }^{2}$ \\ Fakultas Ilmu Administrasi, Universitas Brawijaya, Malang, Indonesia \\ Fakultas Ekonomi dan Bisnis, Universitas Brawijaya, Malang, Indonesia \\ Email: rachmabhaktiutami@gmail.com ${ }^{1}$, kartikasari.dinar46@gmail.com ${ }^{2}$
}

\begin{abstract}
Earnings are the critical indicators of a company's financial performance. Investors' investment decisions can be taken, predicting the company's future growth, and even earnings can determine the unsteady in an institution's stock price. Earning quality in a company's financial reporting is a must because quality earnings are real earnings without earnings management. In 2019, the financial statements of Garuda Indonesia (GI) were quite crowded and caused polemics. The airline with the GIAA issuer code managed to record a net profit of US $\$ 809$ thousand in 2018, inversely proportional to the financial statements of 2017, which lost US\$216.58 million. This performance is quite surprising because, in the third quarter of 2018, the company still lost US\$114.08 million. Otoritas Jasa Keuangan (OJK) also investigated this case until finally, in mid-June 2019, OJK imposed sanctions on the Office of Public Accountants that audited financial statements and imposed fines on Directors of Garuda Indonesia. This case is reminiscent of the importance of applying earnings quality to reporting a company's financial statement.
\end{abstract}

\section{Keywords: Earning Quality, Financial Performance, Garuda Indonesia}

\begin{abstract}
ABSTRAK
Penerapan earnings quality dalam pelaporan keuangan suatu perusahaan sangatlah penting. Laba yang berkualitas atau earnings quality adalah laba yang sebenarnya tanpa adanya manajemen terhadap laba itu sendiri. Laba merupakan satu dari sekian indikator penting dari kinerja suatu perusahaan, karena dengan melihat laba dari suatu perusahaan, keputusan investor untuk melakukan investasi dapat diambil, melakukan prediksi pertumbuhan perusahaan di masa depan, bahkan laba dapat menentukan fluktuasi harga saham suatu perusahaan. Di tahun 2019 ini, pemberitaan mengenai financial statement Garuda Indonesia cukup ramai serta menimbulkan polemik. Perusahaan penerbangan yang memiliki kode emiten GIAA ini tercatat membukukan net income sebesar US\$809ribu pada tahun 2018, sangat kontra dengan laporan keuangan tahun 2017 yang tercatat rugi sebesar US\$216,58juta. Catatan ini cukup menjadi perhatian publik dikarenakan sampai September 2018 Garuda Indonesia tercatat masih rugi sebesar US\$114ribu. Otoritas Jasa keuangan (OJK) pun melakukan investigasi atas kasus ini hingga akhirnya pada pertengahan Juni 2019, OJK memberikan teguran kepada KAP yang melakukan audit serta menjatuhkan denda kepada direksi Garuda Indonesia. Kasus ini mengingatkan kembali pentingnya penerapan earnings quality atas pelaporan laba keuangan suatu perusahaan.
\end{abstract}

Kata Kunci: Kualitas Laba, Kinerja Keuangan, Garuda Indonesia 


\section{PENDAHULUAN}

Untuk meningkatkan eksistensi perusahaan maka diperlukan laba yang positif dan menunjukkan adanya peningkatan. Peranan laba sendiri sangat penting dalam suatu perusahaan baik sebagai tolak ukur kinerja keuangan maupun sebagai indikator prospek pertumbuhan perusahaan dimasa yang akan datang. PT. Garuda Indonesia (Persero) Tbk. sendiri sebagai salah satu perusahaan plat merah tentu dituntut untuk menjaga kualitas laba mengingat kinerja perusahaan BUMN tentu banyak disorot oleh masyarakat luas.

Kinerja GI yang berhasil mencatatkan net income sebesar US\$809ribu pada tahun 2018, berkebalikan dengan laba bersih tahun 2017 yang tercatat rugi sebesar US\$216,58juta. Hal ini tentu menjadi polemik ditengah masyarakat. Pencatatan laba ini cukup mengejutkan lantaran hingga September 2018 saja laba Garuda masih tercatat rugi sebesar US $\$ 114,08$ juta. Chairul Tanjung dan Dony Askaria selaku komisaris Garuda menolak menandatangani financial statement Garuda di tahun 2018 tersebut. Penolakan dilakukan karena adanya kejanggalan terkait kerjasama penyediaan layanan wifi / konektifitas antara Garuda dengan PT. Mahata Aero Teknologi. Transaksi kerjasama yang ditengarai belum ada pembayaran masuk tersebut telah diakui oleh Garuda sebagai pos pendapatan. Kedua komisaris itu sendiri merupakan perwakilan dari PT. Trans Airways, salah satu pemegang saham Garuda sebesar 25,61\%. (cnnindonesia.com, diakses pada 10 Agustus 2019).

Lebih lanjut Chairul Tanjung dan Dony Askaria berpendapat bahwa nominal transaksi dengan Mahata senilai US\$239,94juta terlalu besar dan signifikan berpengaruh di pencatatan laporan keuangan. Pencatatan transaksi dengan Mahata tersebut berpengaruh pada pos neraca keuangan Garuda. Jika nominal transaksi kerjasama tersebut tidak dicatat sebagai pendapatan, maka Garuda sebenarnya masih rugi sebesar US\$244,960juta. Dua komisaris berpendapat efek dari pencatatan transaksi tersebut menimbulkan kerancuan. Pencatatan tersebut menyebabkan pos beban yang ditanggung Garuda menjadi lebih besar. Pembayaran PPN dan $\mathrm{PPh}$ yang harus dilakukan Garuda juga terkerek membesar. Padahal, beban pajak tersebut seharusnya belum wajib dibayar Garuda karena transaksi kerjasama dengan Mahara belum masuk ke keuangan Garuda. (cnnindonesia.com, diakses pada 10 Agustus 2019).

Publik kemudian merespon polemik laporan keuangan Garuda tersebut. Satu hari setelah berita terkait penolakan penandatanganan laporan keuangan oleh komisaris Garuda tersebut tersebar, saham GIAA turun ke angka Rp. 478 per lembar saham, atau turun sebesar $4,4 \%$ dari sebelumnya di angka Rp. 500 per lembar saham. Hingga akhir hari di penutupan perdagangan saham, nilai saham garuda terus merosot tajam sebesar 6,8\% di angka Rp. 466 per lembar saham. Pada akhirnya, per tanggal 28 Juni 2019 kasus laporan keuangan Garuda Indonesia memperoleh teguran dari OJK. Otoritas keuangan Indonesia tersebut melakukan pemeriksaan terkait polemik penyajian financial statement tahunan milik Garuda. (www.cnnindonesia.com), diakses pada 10 Agustus 2019). OJK memberikan sanksi diantaranya memerintahkan secara tertulis kepada Garuda untuk memperbaiki dan menyajikan ulang laporan keuangan tahunan per 31 Desember 2018, serta menyebarluaskan kepada publik terkait re-statement laporan keuangan tersebut, memberikan sanksi berupa denda senilai Rp. 100 juta kepada Garuda terkait penyajian laporan keuangan tahunan, memberikan sanksi berupa denda senilai Rp.100 juta kepada seluruh anggota direksi Garuda serta pembekuan selama satu tahun kepada Kantor Akuntan Publi Tanubrata, Sutanto, Fahmi, Bambang dan Rekan selaku KAP yang melakukan audit atas laporan keuangan tahunan Garuda.

Garuda Indonesia kemudian segera merespon dengan melakukan restatement / memperbaiki dan melakukan re-statement atas financial statement Garuda per tahun buku 31 Desember 2018 sesuai permintaan OJK. Jika sebelum dilakukan re-statement, Garuda Indonesia mencatat laba tahun berjalan pada 2018 sebesar US\$ 5 juta, hasil dari restatement laporan keuangan, perusahaan membukukan rugi tahun berjalan sebesar US\$ 1750 juta atau setara Rp 2,40 triliun pada tahun 2018. (cnbcindonesia.com, diakses pada 10 Agustus 2019). 


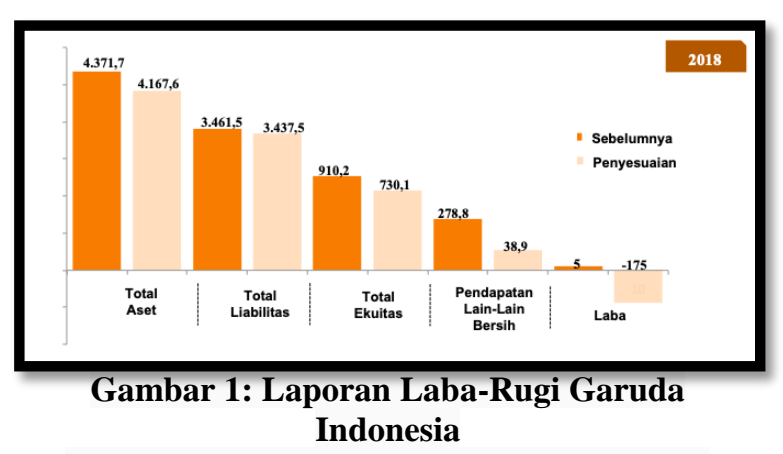

(sumber : berbagai sumber, diolah peneliti)

Dalam pencatatan laporan keuangan, yang dilakukan oleh Garuda Indonesia ini lazim disebut dengan earnings management. Earnings management sendiri merupakan sebagai suatu tindakan yang dipilih oleh manajemen suatu perusahaan untuk menentukan kebijakan terkait akuntasi keuangan dan untuk meraih tujuan perusahaan (Scott, 2013). Sementara Nugroho (2012) mengartikan earnings management sebagai tindakan memanipulasi dalam akuntansi serta pelaporan keuangan. Efek dari earnings management sendiri dapat menurunkan kredibilitas dari financial statement suatu perusahaan, jika perusahaan menggunakan laporan keuangan sebagai sumber pengambilan keputusan (Surifah, 1999). Lebih lanjut, Surifah mengungkapkan bahwa earnings management adalah bentuk manipulasi atas financial statement suatu perusahaan, dimana laporan keuangan ini sendiri sejatinya merupakan bentuk komunikasi antara manajemen perusahaan dengan pihak-pihak dari eksternal perusahaan. Keputusan manajemen perusahaan untuk melakukan earnings management ini sendiri tentu akan menurunkan kualitas laba/ earnings quality dari laporan keuangan suatu perusahaan. Karena laba yang berkualitas adalah laba yang sesungguhnya tanpa adanya manajemen laba di dalam informasi laba yang disampaikan perusahaan. Praktik earnings management yang dipilih oleh management perusahaan akan menyebabkan earnings quality dari pelapotan keuangan menjadi rendah. (Siallagan \& Machfoedz, 2006).

\section{KAJIAN PUSTAKA}

Teori agensi menjadi dasar dimana teori ini menerangkan mengenai hubungan kerjasama antara pemegang saham atau pemilik perusahaan dengan manajemen. Agency theory sendiri ada ketika pemegang saham mempekerjakan orang lain untuk mengoperasikan perusahaan. Agency theory melakukan pembagian kerja antara prinsipal dengan agen / manajemen, (Ulum, 2017). Pada prakteknya, dalam suatu perusahaan, rencana dan tujuan pemegang saham bisa bertolak belakang dengan keinginan pemilik perusahaan. Kondisi ini akan menyebabkan conflict of interest hingga akhirnya timbul masalah keagenan. Masalah keagenan ini sering dikenal dengan istilah agency problem. Dalam mengelola perusahaan, manajemen memiliki dan mengetahui informasi perusahaan yang lebih lengkap dan rinci dibandingkan para pemegang saham. Kondisi ini memunculkan asimetri information / asymetric information. Asymetric information bisa memicu masalah keagenan. Ada potensi manajemen mengolah dan membuat laba sedemikian rupa / earnings management sehingga laporan keuangan yang dihasilkan bisa menguntungkan manajemen namun merugikan pemegang saham.

\section{Penelitian Terdahulu}

Penelitian (Darabi, Kamran Rad, \& Ghadiri, 2012)

Penelitian ini menegaskan bahwa meningkatnya jumlah "fraud" yang disertai dengan kebangkrutan beberapa perusahaan besar menimbulkan kekhawatiran tentang kesehatan dari earnings quality (kualitas laba). Dalam beberapa tahun terakhir, para peneliti dan analis keuangan selain memperhatikan kuantitas pendapatan juga memperhatikan kualitas pendapatan. Kualitas laba sendiri merupakan salah satu aspek yang dapat digunakan perusahaan untuk mengevaluasi kesehatan financial statement perusahaan tersebut. Earnings quality merujuk pada kemampuan earnings yang dipublish menunjukkan penghasilan sebenarnya dari suatu entitas perusahaan, serta fungsi laba yang dilaporkan untuk mengestimasi pendapatan perusahaan di masa yang akan datang. Earnings quality juga mengacu pada stabilitas, persistence dan lack of variability pada laba yang dilaporkan.

\section{Penelitian (Alhadab \& Al-Own, 2017)}

Penelitian yang dilakukan Alhadab \& Al-Own (2017) bertujuan untuk menguji apakah manajemen laba mempengaruhi kinerja bank saat ini dan masa depan. Penelitian ini menganalisis adakah pengaruh antara discretionary loan loss provision dan kedua indikator keuangan perusahaan yakni ROA dan ROE. Menggunakan sampel terdiri dari 477 
pengamatan bank yang mewakili 55 bank Eropa selama periode 2001-2015, terdapat hasil penelitian bahwa bank-bank Eropa dengan tingkat manajemen laba yang tinggi yang ditunjukkan melalui discretionary loan loss provision mengalami kinerja keuangan yang lebih rendah pada tahun sekarang dan selanjutnya. Hasilnya menujukkan bahwa efek negatif earnings management terus berlanjut hingga tahun tahun berikutnya. Hasil analisis dari penelitian ini menekankan implikasi penting bagi banyak pihak yang berkepentingan di seluruh Uni Eropa seperti regulator, investor, perusahaan audit, dan pembuat standar yang bertujuan untuk meningkatkan kualitas pelaporan keuangan di industri perbankan.

\section{Penelitian (Al-Halabi \& Al-Abbadi, 2014)}

Penelitian oleh Al-Halabi \& Al-Abbadi (2014) bertujuan untuk mengetahui dampak dari penerapan indikator kinerja keuangan pada earnings management di perusahaan sektor manufaktur yang tercatat di Amman Stock Exchange. Lima variable eksogen yang diteliti adalah EPS, ROE, dan CR. Sedangkan variable endogen adalah Operating Cash Flow (OCF), dan Net Profits (NP).

Penelitin ini mengadopsi pendekatan deskriptif dan analitik dengan menganalisis laporan keuangan dan laporan sampel perusahaan manufaktur di Yordania menggunakan alat statistik untuk menguji hipotesis penelitian. Data penelitian Al-Halabi \& Al-Abbadi (2014) ini dikumpulkan dari sampel 52 perusahaan manufaktur di periode 2007-2011, serta diproses menggunakan SPSS.

Hasil dari penelitian Al-Halabi \& AlAbbadi (2014) adalah terdapat pengaruh antara ROE dengan earnings management yang dilakukan perusahaan yang tercatat di amman Stock Exchange secara signifikan.

\section{Definisi Earnings Quality}

Laba menjadi informasi yang dibutuhkan oleh pihak terkait yang menggunakan financial statement baik pihak internal perusahaan maupun pihak eksternal. Laba dapat menjadi indikator untuk mengetahui operasional entitas perusahaan serta juga dapat menilai sukses atau tidaknya bisnis dalam meraih tujuan perusahaan. Informasi mengenai laba bermanfaat bagi pengambilan keputusan di masa mendatang seperti keputusan untuk investasi maupun keputusan pemberian pinjaman.
Kualitas laba mencakup enam karakteristik yang meliputi nilai prediksi, nilai umpan balik, tepat waktu, netralitas, penyajian yang jujur dan keterujian (Surifah, 1999). Kemudian menurut (Givoly et al, 2009) sebagaimana dikutip (Surifah, 1999) ukuran kualitas laba-dapat dilihat dari sisi persistensi, karena laba yang berkualitas ditunjukkan melalui laba yang berkelanjutan / persistence. Earnings Quality juga terlihat dengan sifatnya yang permanen, serta tidak bersifat transitori. Persistence sebagai sifat dari earnings quality ini ditentukan dari sudut pandang manfaat dari laba sebagai sarana pengambilan keputusan, khususnya dalam upaya menentukan nilai ekuitas dari entitas perusahaan. Earnings quality juga dapat dilihat dari kemampuan laba dalam memprediksi adanya suatu informasi tertentu, seperti memprediksi earnings di masa yang akan datang.

Hal terpenting dalam penerbitan financial statement adalah informasi mengenai laba serta komponen yang terkait laba. Informasi laba dapat digunakan oleh para pengguna laporan keuangan untuk menilai kinerja managemen, mengestimasi earnings power serta laba di masa depan, serta mengidentifikasi resiko suatu perusahaan. Dikarenakan earnings sering digunakan sebagai acuan investor dalam berinvestasi, maka laba yang dilaporkan harus berkualitas. Ketika laba perusahaan berkualitas maka menunjukkan kinerja keuangan perusahaan yang semakin baik pula. Alhadab \& Al-Own (2017) menunjukkan bahwa earning yang ditunjukkan melalui discretionary loan loss provision/ $D L L P$ berhubungan positif dengan kinerja operasional ( $R O A$ dan $R O E$ ) saat ini maupun di masa depan.

Peranan laba sangat penting bagi suatu perusahaan, baik sebagai tolak ukur kinerja keuangan maupun untuk melihat prospek pertumbuhan perusahaan dimasa yang akan datang (Alhadad dan Al-Own, 2017). Kualitas laba menjadi poin positif sebagai nilai tambah perusahaan, namun dikarenakan krusialnya pelaporan laba di laporan keuangan menyebabkan manajemen besar kemungkinan melakukan tindakan yang membuat financial statement tampak lebih baik. Upaya manajemen untuk memanipulasi laba untuk mencapai tujuan tertentu seperti yang ditargetkan atau ekspektasi yang ditetapkan oleh para analis atau angka-angka sejalan dengan memperlancar pendapatan aktual yang berakhir dengan 
keuntungan tetap (Al-halabi dan Al-Abbabi, 2014).

\section{Pengukuran Earnings Quality}

Variable earnings quality diukur melalui beberapa indikator diantaranya discretionary accruals, earnings persistence, accruals quality dan earnings predictability (Kothari, 2005).

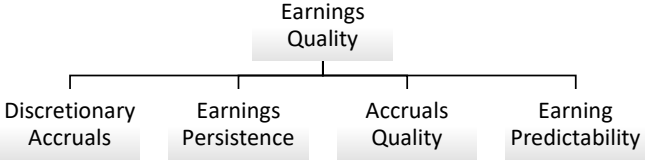

Gambar 2. Pengukuran Earnings Quality (Sumber: Jones, 1991)

\section{Discretionary Accruals}

Discretionary accruals dilakukan dengan model (Beaver \& Engel, 1996) dengan urutan sebagai berikut.

a. Menentukan angka koefisien estimasi dengan melakukan regresi persamaan berikut.

$T A_{i t}=\beta 0+\beta_{1}$ Coit $_{\text {it }}+\beta_{2}$ Loanit $_{i t}+\beta_{3} N P A_{i t}+\beta_{4} \Delta N P A_{i t}+e_{i t}$

(Sumber: Beaver \& Eager, 1996)

b. Menghitung nilai non discretionary accruals dengan mensubstitusikan nilai koefisien estimasi sesuai persamaan berikut.

$N D A_{i t}=T_{A}-\left(\beta_{0}+\beta_{1}\right.$ coit $+\beta_{2}$ Loan $\left._{i t}+\beta_{3} N P A_{i t}+\beta_{4} \Delta N P A_{i t+1}\right)$

(Sumber: Beaver \& Eager, 1996)

c. Menghitung nilai discretionary accruals dengan rumus berikut.

$$
\mathrm{DA}_{\text {it }}=\mathrm{TA}_{\mathrm{it}}-\mathrm{NDA}_{\text {it }}
$$

(Sumber: Beaver \& Eager, 1996)

\section{Earnings Persistence}

Earnings persistence atau persistensi laba adalah suatu ukuran yang menunjukkan kapasitas perusahaan untuk menjaga laba yang diperoleh saat ini hingga satu periode di masa yang akan datang. Earnings persistence juga menjadi nilai prediktif yang ditunjukkan dalam komponen akrual serta aliran kas. Jika komponen akrual serta aliran kas dapat mempengaruhi laba sebelum pajak di masa yang akan datang, maka akan mempunyai laba yang persistence (Hanlon, 2005). Earnings persistence menangkap keberlanjutan pendapatan, dan dengan demikian, pendapatan persisten dipandang sebagai hal yang diinginkan karena mereka berulang (Francis et al. 2004). Presistensi laba diukur melalui Kormendi dan Lipe (1987) dengan rumus sebagai berikut.

$$
\frac{\text { Earn }_{j, 1}}{\text { Assets }_{j,-1}}=\delta_{0}+\delta_{1} \frac{\text { Earn }_{j,-1}}{\text { Assets }_{j,-1}}+v_{j,}
$$

(Sumber: Jones, 1991)

\section{Accruals Quality}

Gap antara earnings dan cash disebut accruals. Pendapatan / earnings yang dekat ke arus kas adalah pendapatan yang diinginkan oleh perusahaan. Salah satu peran accruals adalah melakukan penyesuaian arus kas dari satu periode ke periode lain, sehingga didapat angka yang lebih mencerminkan performance dari suatu perusahaan.

$$
\frac{\text { CCA }_{j,}}{\text { Assets }_{j,-1}}=b_{0}+b_{1} \frac{\text { CFO }_{j,-1}}{\text { Assets }_{j, t-1}}+b_{2} \frac{C F O_{j,}}{\text { Assets }_{j,-1}}+b_{3} \frac{C F O_{j, t+1}}{\text { Assets }_{j, t-1}}+\varepsilon_{i,}
$$

(Sumber: Jones, 1991)

TCAj.t menunjukkan Total Current Accruals perusahaan di tahun t, Assets j.t-1 merupakan total asset suatu perusahaan di tahun $\mathrm{t}-1$, sementara CFO adalah cash flow operasional suatu perusahaan.

\section{Earnings Predictability}

Earnings Predictability mengacu pada kemampuan earnings / penghasilan untuk dapat diprediksi dalam interval waktu tertentu. (Jones, 1991)mengukur prediktabilitas pendapatan menggunakan root of the estimated error variance dari earnings persistence equation. Langkah-langkah perhitungannya adalah sebagai berikut.

$$
\text { Pred }_{i j}=\sqrt{\sigma^{2}\left(\hat{v}_{i j}\right)}
$$

(Sumber: Jones, 1991)

\section{METODE PENELITIAN}

Jenis penelitian ini adalah penelitan kepustakaan (library research), yaitu serangkaian penelitian yang berkenaan dengan metode pengumpulan data pustaka, atau penelitian yang obyek penelitiannya digali melalui beragam informasi kepustakaan (buku, 
ensiklopedi, jurnal ilmiah, koran, majalah, dan dokumen). Penelitian kepustakaan atau kajian literatur (literature review, literature research) merupakan penelitian yang mengkaji atau meninjau secara kritis pengetahuan, gagasan, atau temuan yang terdapat di dalam tubuh literatur berorientasi akademik (academicoriented literature), serta merumuskan kontribusi teoritis dan metodologisnya untuk topik tertentu. Fokus penelitian kepustakaan adalah menemukan berbagai teori, hukum, dalil, prinsip, atau gagasan yang digunakan untuk menganalisis dan memecahkan pertanyaan penelitianyang dirumuskan.

\section{KESIMPULAN DAN SARAN \\ Kesimpulan}

Berdasarkan hasil kajian mengenai kualitas laba dalam studi kasus pelaporan financial statement Garuda Indonesia dapat disimpulkan bahwa Garuda Indonesia melakukan earnings management dalam pelaporan atas laporan keuangannya. Kondisi ini tentu merugikan beberapa pihak khususnya pemegang saham dari Garuda Indonesia. Efek dari penerapan earnings management di Garuda Indonesia diantaranya seperti denda kepada direksi, saham GIAA yang menurun, belum lagi reputasi Garuda Indonesia yang turun di mata masyarakat sebagai akibat dari kasus ini.

\section{Saran}

Kedepannya diharapkan seluruh perusahaan dapat belajar dari kasus laporan keuangan Garuda Indonesia, sehingga dapat menerapkan pelaporan laba keuangan perusahaan yang berkualitas, karena beberapa kajian penelitian terdahulu telah menunjukkan hasil bahwa laba yang berkualitas / earnings quality berpengaruh signifikan dan positif terhadap financial performance atau kinerja suatu perusahaan. Selain itu, seluruh perusahaan, dari sektor manapun, baik perusahaan pemerintah maupun perusahaan swasta untuk tidak melakukan earnings management atas keuangan perusahaan, karena meskipun laba perusahaan terlihat baik akibat dilakukannya earnings management, namun dalam jangka panjang akan memberikan dampak buruk bagi kinerja keuangan suatu perusahaan.

\section{DAFTAR PUSTAKA}

AL-Hadab, M. M., \& Own, B. A.-. (2017). Earnings Management and Banks Performance: Evidence from Europe. International Journal of Academic Research in Accounting, Finance and Management Sciences, 7(4), 134-145. https://doi.org/10.6007/ijarafms/v7i $4 / 3444$

Al-Halabi, N. B. (2014). The Impact of Applying Financial Performance Indicators on Earnings Management in Manufacturing Companies. European Journal of Business and Management, 6(24), 80-87.

cnnindonesia. (n.d.). Lapkeu Cacat, Direksi dan Komisaris Garuda Didenda Rp100 Juta. Retrieved August 10, 2019, from https://www.cnnindonesia.com/ekonomi/ 20190628113411-92-407273/lapkeucacat-direksi-dan-komisaris-garudadidenda-rp100-juta

Darabi, R., Kamran Rad, S., \& Ghadiri, M. (2012). The relationship between intellectual capital and earnings quality. Research Journal of Applied Sciences, Engineering, and Technology, 4(20), 4192-4199.

Givoly, D., Hayn, C., \& Katz, S. P. (2009). Working Paper 09-105. Business.

Jones, J. (1991). Earnings Management during Import Relief Investigation. Journal of Accounting Research, 29, 193-228.

Kothari, S. . (2005). Performance Matched Discretionary Accrual Measures. Journal of Accounting and Economics, 39, 163197.

Nugroho, B. Y. (2012). Board Characteristics and Earning Management. Jurnal Ilmu Administrasi Dan Birokrasi, 18(1), 1-10. https://doi.org/10.20476/jbb.v18i1.969

Scott, W. R. (n.d.). Financial Accounting Theory (Fifth Edit). Toronto: Pearson Prentice Hall.

Siallagan, H., \& Achfoedz, M. (2006). Mekanisme Corporate Governance, Kualitas Laba dan Nilai Perusahaan. Simposium Nasional Akuntansi 9 Padang, (061), 23-26. 
Surifah. (1999). Informasi Asimetri dan Pengaruh Manajemen Laba Terhadap Pelaporan Keuangan dalam Perspektif Agency heory. Jurnal Kajian Bisnis, 1, $71-81$.

Ulum, I. (2017). Intellectual Capital (3rd ed.). Malang: UMM Press. 